Katarzyna Pyka

(D) https://orcid.org/0000-0002-8253-6751

Wydział Sztuki i Nauk o Edukacji, Uniwersytet Śląski

\title{
W skali szarości - krótka historia srebrzystego ołowiu łączącego kolorowe szkła witrażowe
}

\author{
In Grayscale - a Brief History of Silvery Lead \\ Used to Combine Color Stained Glass
}

\begin{abstract}
Aвstract: Katarzyna Pyka discusses lead as a substance which for centuries has made possible stained glass glazing both in sacral and secular buildings. This article focuses on the uses of lead and compares the work of stained glass artists in the past and today. Contrary the associations of this craft with vivid multicolored compositions, Pyka has decided to keep her discussion in grayscale; her purpose has been to emphasize the importance of this silvery metal, which has enriched the history of art from the Middle Ages by making possible the beauty of stained glass compositions.
\end{abstract}

KEY wORDs: lead, stained glass, arts, crafts, glass

W tym krótkim opracowaniu chciałabym przybliżyć funkcję, jaką pełni ołów w sztuce witrażu. Pragnę pisać z punktu widzenia nie tylko artysty i projektanta, ale też z punktu widzenia rzemieślnika, wyrazić szacunek do przeszkleń witrażowych zarówno tych dawnych, jak i współczesnych, szacunek w równej mierze dla kreacji, jak i rzetelnej realizacji. 
W 2002 roku ukończyłam na Akademii Sztuk Pięknych im. Eugeniusza Gepperta we Wrocławiu studia podyplomowe z zakresu witrażu w pracowni Profesora Ryszarda Więckowskiego. Od tego czasu szkło stało się dla mnie podstawowym medium wypowiedzi artystycznej. Dobra znajomość materii nie tylko dała mi nieograniczone możliwości kreowania poprzez rysunek, ale także pozwoliła wykorzystywać różnorodną strukturę szkła, posługiwać się niuansami błysku i matu oraz środkami malarskimi. Dyplomową pracę magisterską zrealizowałam z grafiki artystycznej, dlatego bliskie są mi wszelkie odcienie szarości oraz kontrast pomiędzy czernią i bielą. W mojej twórczości kolor pojawia się rzadko - jedynie jako akcent. Powierzchnia wykonywanych przeze mnie witraży jest $\mathrm{w}$ dużym stopniu chropowata, matowa, biała i nie zawsze przezroczysta. Kompozycje są rodzajem zapisu pamięci lub raczej wyobrażeniem tego, co zapomniane, przypomnieniem o przemijaniu, o bezwzględnym wpływie czasu na człowieka. Każdy z witraży jest poetycką wizją odnoszącą się do przeszłości, próbą powstrzymania zapomnienia. Materia szkła buduje fragmenty mojej rzeczywistości, pozwala rejestrować postrzeganie świata. Moment dostrzeżenia, chwila wyboru - wszystko staje się istotne. Kolejne wybrane kadry, czasami podobne, różniące się tylko niuansami, to jakby spojrzenie na tę samą materię z innej perspektywy, w innym czasie. Subtelne różnice, mocne kontrasty, pęknięcia i rysy, fragmenty zapisów, składają się na moje pole widzenia, natomiast linia ołowiu, geometryczna lub biologiczna, jednocześnie oddziela i scala kontrastowe płaszczyzny szkła (fot. 1 i 2 ).
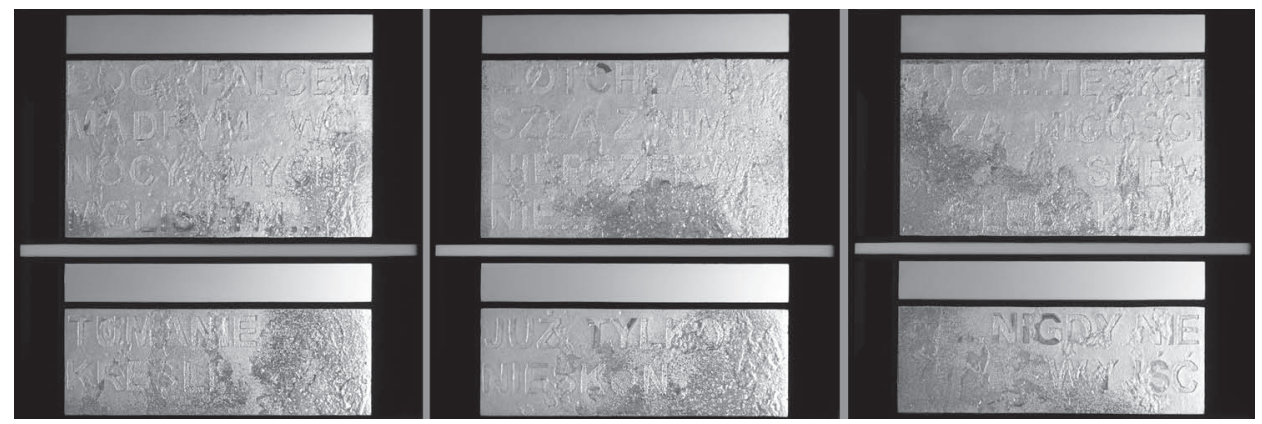

Fot. 1. 


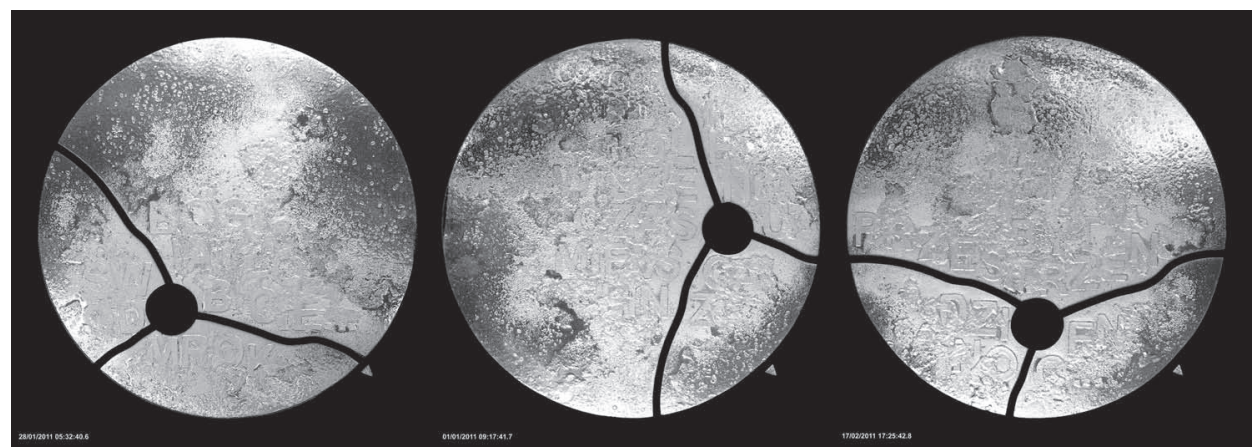

Fot. 2.

Ołów nie tylko pozwala na łączenie poszczególnych szkieł w całość, ale przede wszystkim tworzy wspaniały rysunek, dopełnia kompozycję, określa motywy, rozstrzyga o ekspresji. Jego oddziaływanie na ostateczny wyraz dzieła wydaje się najbardziej widoczne w okresie secesji czy art déco. Wówczas stanowił on wręcz podstawę przeszkleń witrażowych. Dlatego po krótkim wstępie przedstawiającym moje spojrzenie na sztukę witrażu pragnę skupić się już na samej istocie srebrzystego ołowiu. Aby w pełni pokazać jego wartość, będę musiała zdradzić wiele tajników artysty zajmującego się tym szlachetnym rzemiosłem. Niesamowite jest to, że sposób wykonywania witraży nie zmienił się zasadniczo od czasów średniowiecza. Wtedy łączenie szkieł przy użyciu ołowiu wynikało jeszcze z braku umiejętności wytwarzania dużych tafli szklanych. W tym czasie w katedrach zaczęto projektować coraz większe okna, wymagające ogromnych przeszkleń witrażowych, dlatego łączono niewielkie, kolorowe, szklane tafelki ołowiem o przekroju litery $\mathrm{H}$. Te szkła malowane patynami oraz emaliami do dziś można podziwiać w wielu świątyniach. Zacytujmy samego Mnicha Teofila, zajmującego się tym rzemiosłem na przełomie XI i XII wieku, który tak pisał o wytwarzaniu $\mathrm{w}$ średniowieczu kształtek ołowianych oraz przygotowywaniu z żelaza bądź drewna jodłowego formy do odlewania:

Przygotować należy dwa kawałki żelaza, o szerokości dwóch palców i grubości jednego oraz długości jednego łokcia. Łączy się je potem razem z jednego końca na sposób zawiasów [...]. Następnie rozdziela się je od siebie i przy 
pomocy liniału robi się w środku jednej części dwie linie, w drugiej części naprzeciw w środku także dwie - od góry aż do dołu w niewielkiej odległości od siebie; wybiera się je potem na stosowną głębokość dłutem, którym żłobi się świeczniki i inne odlewy; następnie obydwie części od wewnątrz między dwiema wyrysowanymi liniami opiłowuje nieco pilnikiem, aby gdy wleje się między nie ołów, stanowiły jeden kawałek ${ }^{1}$.

Trzeba dodać, że następnie $\mathrm{w}$ glinianym tygielku, umocnionym jeszcze gliną z nawozem, topiono $\mathrm{w}$ ognisku ołów i wlewano $\mathrm{w}$ tak przygotowane formy. Jeśli forma miała długość tylko jednego łokcia, to wytworzony ołów mógł mieć zaledwie około $50 \mathrm{~cm}$ długości. Można sobie wyobrazić, jak wiele takich kształtek należało przygotować, aby przeszklić okno w gotyckiej katedrze benedyktyńska cierpliwość nabiera w tym kontekście realnych kształtów. Ile surowca należało stopić i ile odlać niewielkich kształtek, narażając się przy tym na działanie szkodliwych oparów? Dla przykładu: na jedną średniej wielkości kwaterę witrażową $(900 \times 1200 \mathrm{~mm})$ przygotowuję około $20 \mathrm{~m}$ ołowiu, czyli w czasach średniowiecznych należało odlać aż 40 elementów, a mowa tu o jednej kwaterze okiennej, a nie o kilkumetrowym gotyckim oknie witrażowym.

Dziś przygotowanie ołowiu nie wymaga już takiego nakładu pracy i na szczęście nie trzeba go przetapiać, choć jeszcze do niedawna była to spotykana praktyka, sama w sobie bardzo szkodliwa. Obecnie można kupić gotowe kształtki, jednak w większości są one zbyt twarde, aby składać bardzo skomplikowane formy. Zawierają one domieszki cyny i są powlekane specjalnymi olejami zabezpieczającymi przed utlenianiem. Dlatego zdecydowanie preferuje się użycie ołowiu, który został przygotowany samodzielnie podczas walcowania go na odpowiedniej maszynie. W hucie zamawia się tzw. bruk - jest to profil ołowiany o przekroju litery H (99,97\% czystego ołowiu), ale znacznie grubszy (fot. 3). Tnie się go na około 40-centymetrowe kawałki, aby z takiego fragmentu uzyskać kształtkę niemal dwumetrową. Artysta sam decyduje o wysokości serca (najczęściej jest to $4,5 \mathrm{~mm}$ ) oraz o szerokości płetewki, która może mieć rozmiar 3-10 mm, a nawet więcej - w zależności od tego, jaką kreskę ołowiu chce się uzyskać (fot. 4). Katowicka huta w Szopienicach również dostarczała

${ }^{1}$ T. Prezbiter: Diversarum Artium Schedula i inne średniowieczne zbiory przepisów o sztukach rozmaitych. Tyniec. Wydawnictwo Benedyktynów, Kraków 2009, s. 45. 


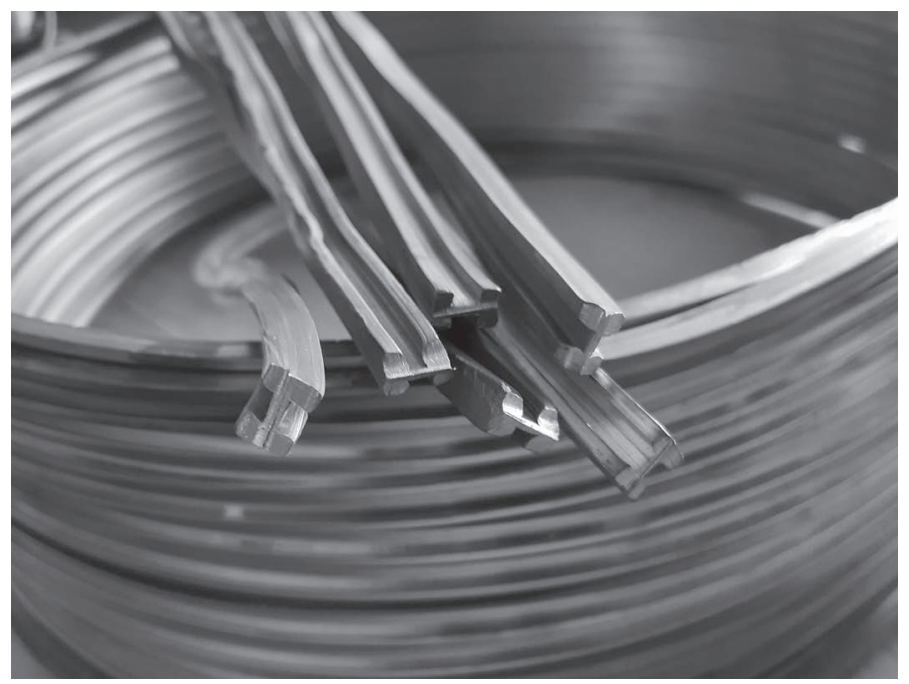

Fot. 3.

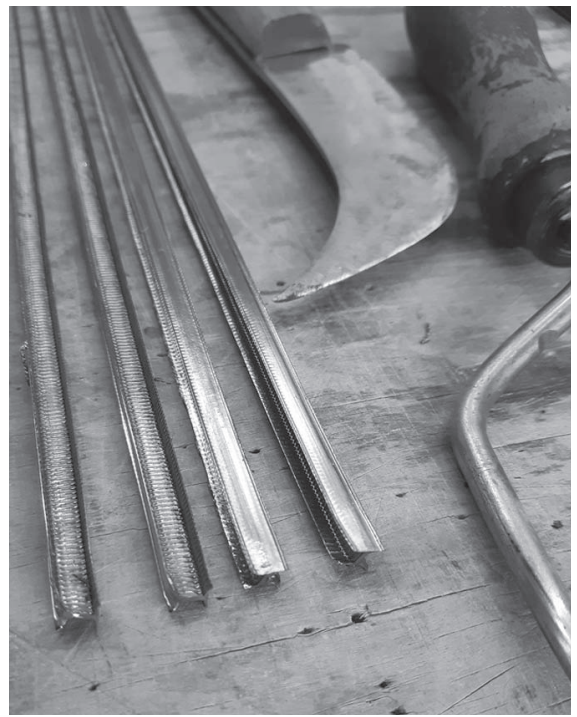

Fot. 4. 
witrażystom wstępną formę ołowiu, jaką jest „bruk”; obecnie robi to firma Baterpol, znajdująca się na terenach dawnej huty. Jednak aby przygotować samodzielnie profile ołowiane, trzeba posiadać odpowiednią maszynę do walcowania gotowych kształtek. Na zdjęciu 5 można zobaczyć wnętrze takiego urządzenia: u dołu widać kółko regulujące wysokość serca oraz szczękę określającą szero-

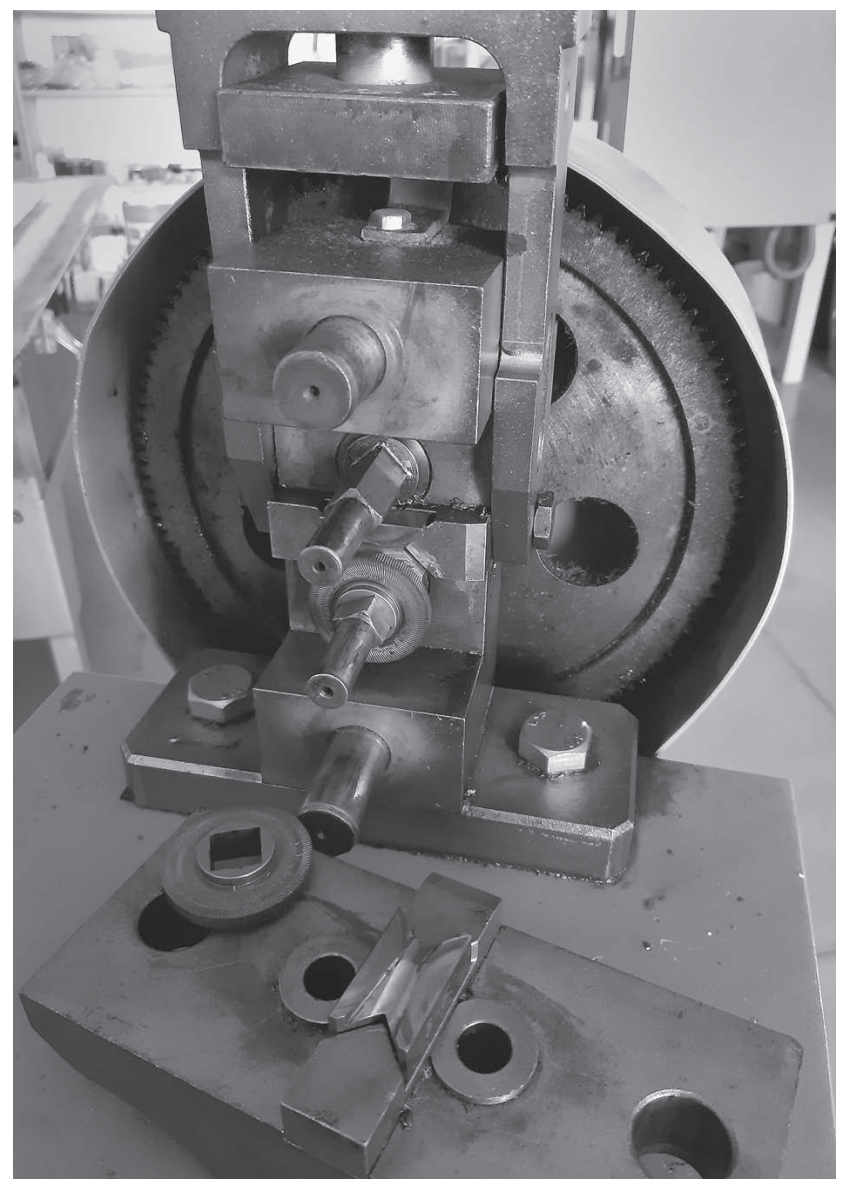

Fot. 5 . 
kość płetewki. Moja blisko pięćdziesięcioletnia walcarka, którą zakupiłam dwadzieścia lat temu, po niewielkim remoncie oraz wymianie precyzyjnych kółek i szczęk służy mi bardzo dobrze i mam nadzieję, że pozwoli mi na przeciągnięcie jeszcze wielu metrów ołowiu, który jest idealnym materiałem łączącym ze sobą twarde i kruche szkło. Ze względu na swoje właściwości, miękkość i podatność na formowanie, pozwala zespalać ze sobą nawet najbardziej skomplikowane kształty. Po kilku latach składania witraży, gdy doliczyłam się ponad trzystu zrealizowanych kwater - przestałam liczyć, ale ciągle każda z nich jest dla mnie oddzielną historią, przygodą i doświadczeniem. Często na pokazach wykonywania witraży słyszę pytanie: skąd wiem, jaka jest kolejność układania szkieł? Odpowiadam - to podział ołowiu mnie prowadzi i podpowiada kolejność, czasami też daje wiele możliwości wyboru, wtedy sama muszę decydować, jaki kierunek będzie najlepszy (fot. 6 i 7).

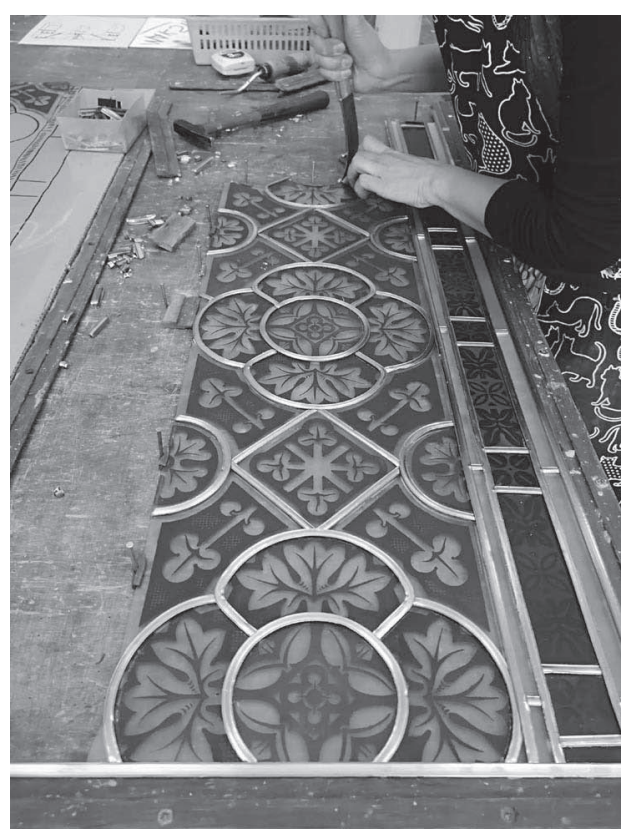

Fot. 6.

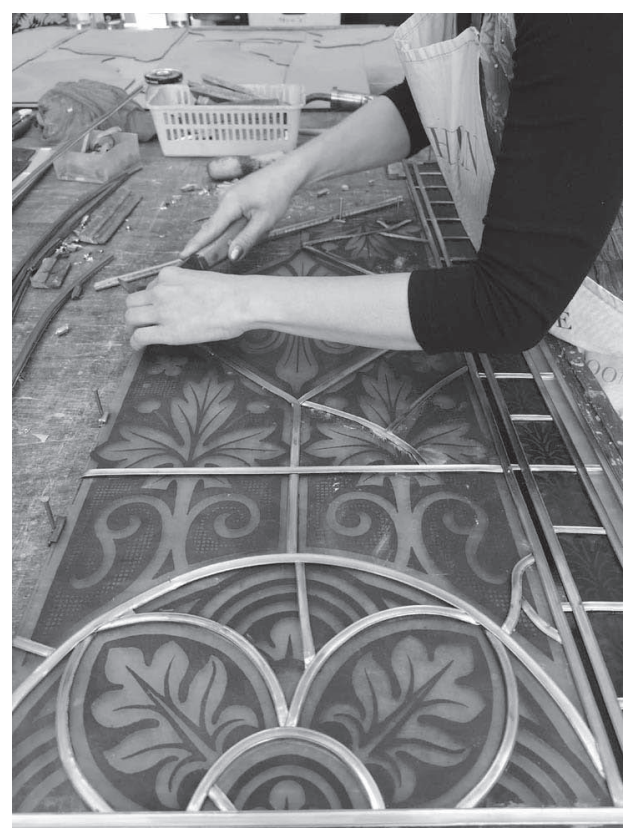

Fot. 7. 
Na przestrzeni wieków zmieniła się estetyka projektowania, ale podstawy technologiczne przetrwały. Na pewno obecna technologia ułatwia nam produkcję profili ołowianych, nie ogranicza wielkości szkieł, poszerza wachlarz farb witrażowych, jednak ciągle sztuka ta wymaga cierpliwości i wielu umiejętności, począwszy od projektowania, wycinania szkieł czy znajomości witrażowych technik malarskich. Zanim przejdę do szczegółów, przywołam jeszcze opis składania witraży zamieszczony w Diversarum Artium Schedula...:

Bierze się następnie szkło pomalowane i wypalone i układa się je w odpowiednim porządku na drugiej części płyty, na której nie ma żadnego malowidła. Wziąwszy następnie głowę jednej postaci i okoliwszy ołowiem, kładzie się ją ostrożnie na swoje miejsce i przybija trzema gwoździami odpowiednim do tego młotkiem; dołącza się do niej następnie pierś i ramiona oraz pozostałe szaty; którąkolwiek część się dołoży, trzeba ją przytwierdzić od zewnątrz gwoździami, aby nie mogła się ruszyć ze swego miejsca. [...] Kiedy postaciom zostaną nadane kształty, w podobny sposób układa się tła, w jakim się chce kolorze. I tak, tak kawałek po kawałku, składa się witraż. Ukończone, zlutowane $\mathrm{z}$ jednej strony kawałki witrażu, należy obrócić na drugą stronę, w podobny sposób oskrobać i wszędzie polutować ${ }^{2}$.

Dziś jest trochę inaczej, prace rozpoczyna się od krawędzi witraża, wspierając go przy składaniu na prostopadłych, wyprofilowanych listwach drewnianych. Do unieruchomienia poszczególnych szkieł używa się również stożkowatych gwoździ, ale stosuje się też odpowiednie ołowiane i drewniane dystanse zabezpieczające przed uszkodzeniem zarówno szkła, jak i ołowiu (fot. 8). Oczywiście, punktem wyjścia powstania witraży jest projekt, nie tylko podziału ołowiu, ale i malatury, jednak w tym artykule chcę skupić się na samym ołowiu, dlatego pomijam projektowanie malatur. Rysunek podziału elementów witrażu przenosi się precyzyjnie na karton o odpowiedniej gramaturze, a jego kopię wykonuje się na folii. Każde szkło trzeba ponumerować, aby po rozcięciu szablonów z kartonu zachować ich kopię na folii. Szablony rozcina się specjalnymi nożyczkami posiadającymi trzy ostrza - dwa dolne i jedno górne. Wycinają one przestrzeń na serce ołowiu, czyli odcinają cienki pasek papieru szerokości około 1,5 mm -

\footnotetext{
${ }^{2}$ Tamże, s. 47.
} 


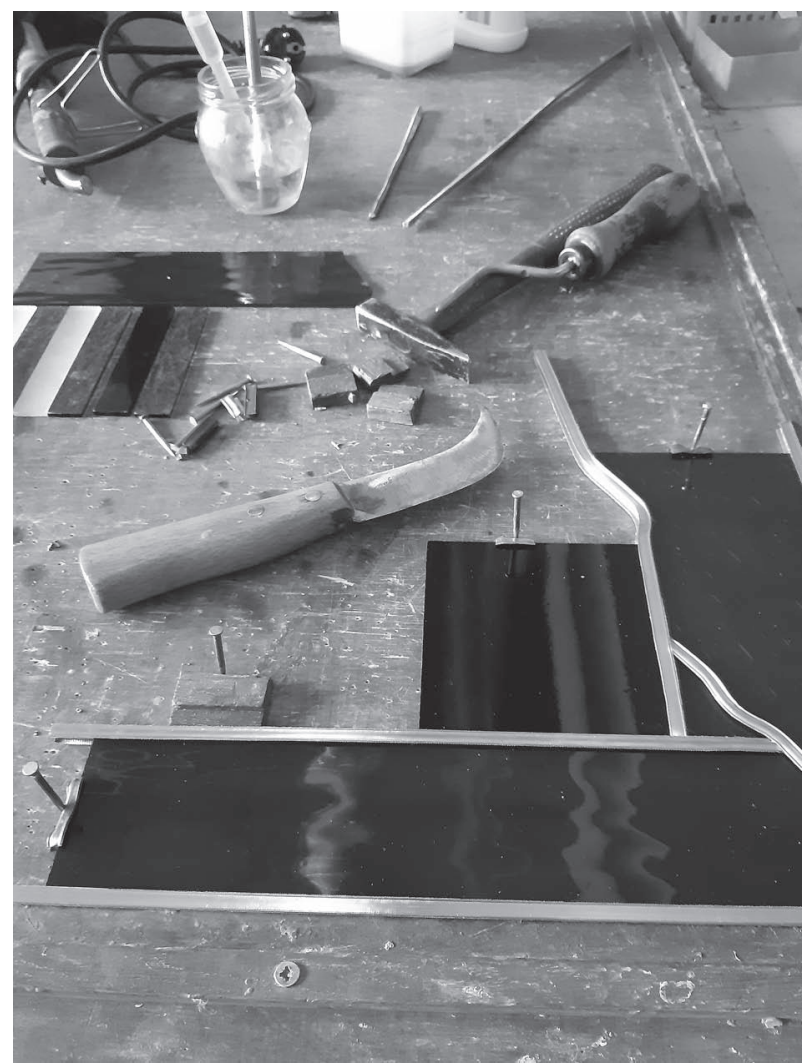

Fot. 8 .

w tym miejscu znajdzie się serce ołowiu. Dopiero od tak przygotowanych szablonów bardzo precyzyjnie wycina się szkła.

Chciałabym wspomnieć jeszcze o farbach witrażowych, ponieważ zanim poszczególne szkła złoży się w całość, maluje się je czarnym konturem witrażowym oraz szarymi i kolorowymi patynami i emaliami. One również zawierają w sobie związki ołowiu, jednak obecnie producenci ze względów bezpieczeństwa wycofują ze składu tych produktów szkodliwy metal, co niestety obniża ich jakość. Dzięki malaturom witrażowym można uzyskać nieograniczoną paletę barw, nakładając je cierpliwie, warstwa po warstwie, i utrwalając każdą z nich 
w temperaturze od 570 do $630^{\circ} \mathrm{C}$. Kolory łączą się ze sobą, tworząc różnorodne wartości estetyczne: od delikatnych przejść tonalnych aż po intensywne kontrasty; dają twórcom nieograniczone możliwości wyrazu artystycznego.

W trakcie składania gotowych szkieł witrażowych do przycinania ołowiu używa się specjalnie wyprofilowanych noży o finezyjnych formach. Przykładowo, widniejący na fotografii 9, przedstawiającej moją kolekcję, trzeci nóż od lewej

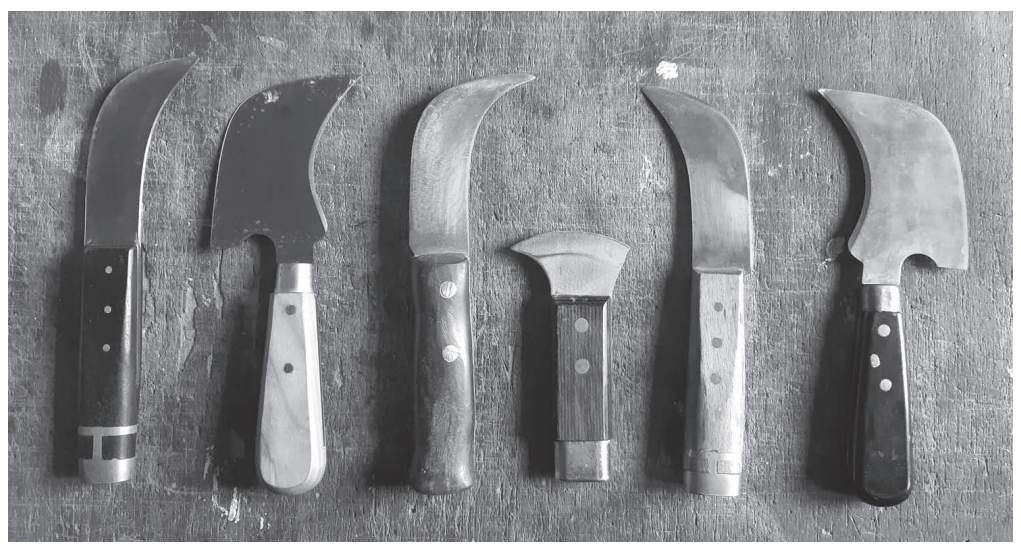

Fot. 9 .

ma idealnie wyprofilowane ostrze o cienkiej ściance, co pozwala na bardzo precyzyjną pracę. Po ukończeniu składania następuje proces lutowania. W czasach średniowiecza natomiast robiono to następująco:

Po ukończeniu powyższych prac, należy wziąć czystej cyny oraz domieszać do niej piątą część ołowiu i w wymienionej wyżej formie żelaznej lub drewnianej odlać tyle, ile się chce prętów, którymi można będzie zlutować dzieło. [...] Dopiero wtedy winno się wziąć lutownicę, która musi być długa i cienka, przy końcu zaś grubsza i zaokrąglona, na samym czubku okrągłości przycięta szpiczasto, opiłowana i ocynkowana, i włożyć do ognia. [...] wziąć rozgrzaną lutownicę, nałożyć na nią cyny i w miejscach, w których schodzą się ze sobą dwa kawałki ołowiu, przeciągnąć lutownicą, aż one do siebie przylgnąa ${ }^{3}$.

\footnotetext{
${ }^{3}$ Tamże.
} 
Dziś do lutowania używa się gotowego stopu zawierającego 60\% cyny i $40 \%$ ołowiu, bez dodatku topnika. Topnik stanowi olej stearynowy, który powoduje idealne płynięcie cyny po rozgrzanym ołowiu. Dawniej witraże lutowane były punktowo, tylko na złączeniach, dziś najczęściej pokrywa się ołów w całości cyną (fot. 10), wzmacniając go w ten sposób i uodparniając na utlenianie, które osłabia jego strukturę. Największa kwatera witrażowa, jaką kiedykolwiek składałam, miała $1600 \times 1400 \mathrm{~mm}$ i złożona była z ponad 400 szkieł. Przy takich realizacjach precyzja wycinania i składania jest wyjątkowo ważna. Każdy witraż

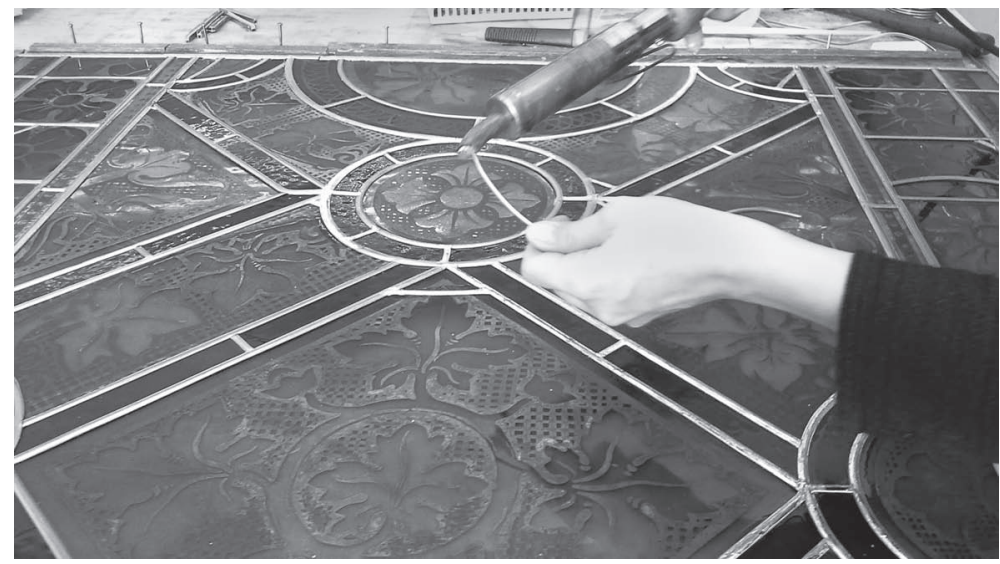

Fot. 10

po dogięciu ołowiu i zalutowaniu frontu jest bardzo wiotki, dlatego trzeba umiejętnie obrócić go na drugą stronę. Przy tak dużej kwaterze, o jakiej pisałam, trzeba przewracać ją pomiędzy dwoma ściśniętymi ze sobą blatami stołu. Dopiero wtedy można wykończyć przeciwną stronę, ponownie zlutować i uszczelnić kitem (fot. 11). Tak naprawdę kwatera nabiera sztywności dopiero po włożeniu w ramy drewniane lub stalowe. Kiedyś witraże były jedynymi przeszkleniami okiennymi, dziś najpierw zabezpieczamy okno specjalistycznym szkłem, dopiero potem montujemy witraż. Dlatego dawniej, aby wzmocnić kwaterę, stosowano tzw. wiatrownicę (fot. 12). Był to pręt stalowy wmontowany w ramę i zamocowany za pomocą cienkich, przylutowanych do ołowiu drucików. Dzięki temu 
302 Ołów/ołowica w kulturze i nauce

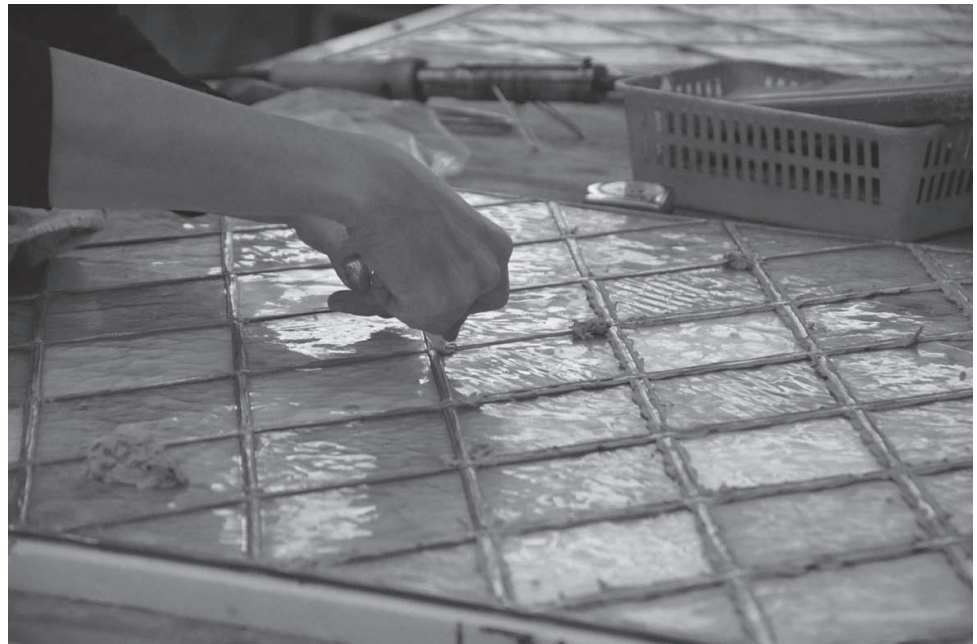

Fot. 11.

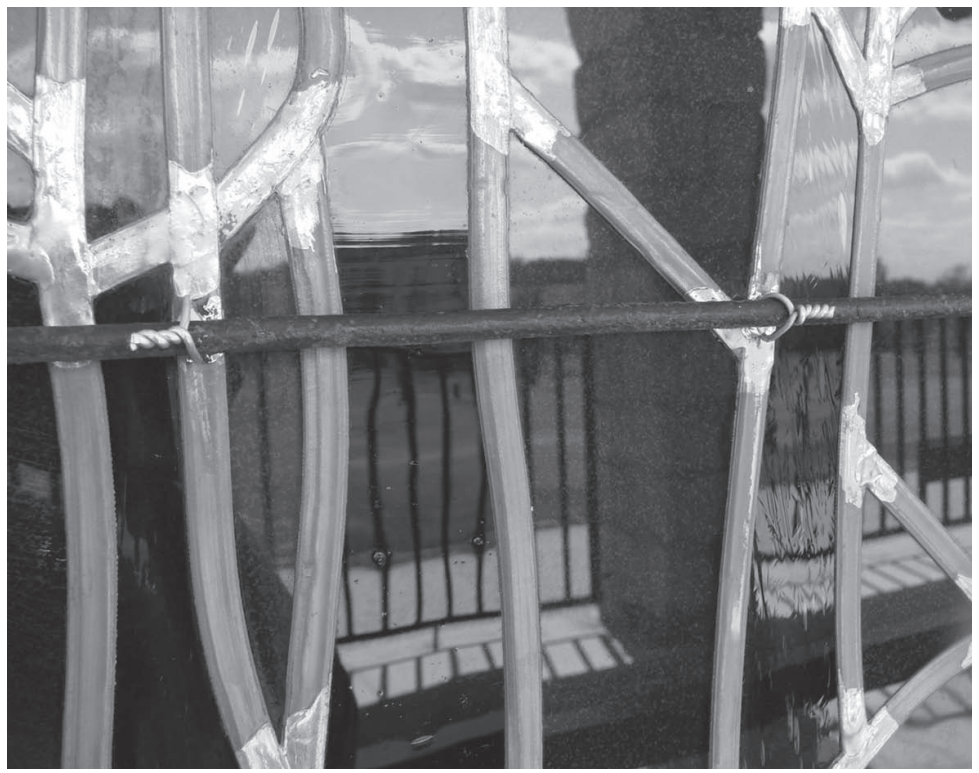

Fot. 12. 
kwatera nabierała sztywności i była uodporniona na warunki atmosferyczne. Dziś mamy do dyspozycji ołów ze specjalnym rdzeniem stalowym, który może spełniać funkcję ówczesnej wiatrownicy, musi być jednak umiejętnie wkomponowany, aby zarazem podkreślał kompozycję i wzmacniał konstrukcję.

Na zakończenie muszę napisać jeszcze kilka słów o renowacji, która jest mi szczególnie bliska, ponieważ pozwala na kontakt z przeszłością i jest rodzajem dialogu z dawnymi czasami. Obecnie wiele zabytkowych witraży trafia do konserwacji. Niektóre $\mathrm{z}$ nich są $\mathrm{w}$ na tyle dobrym stanie, że wymagają tylko dokładnego wyczyszczenia. Niestety, większość potrzebuje bardziej profesjonalnych i skomplikowanych działań, ponieważ trzeba w nich wymienić wszystkie ołowiane elementy oraz uzupełnić ubytki szkieł i malatury. Starego ołowiu nie wyrzuca się - po rozebraniu kwatery oddaje się go do przetopienia; najistotniejsze jest zachowanie starych szkieł, które oprawia się ponownie w nowe kształtki.

Tak jak wspomniałam, wiele zabytkowych witraży przetrwało do dziś. Oczywiście, czas spowodował, że szkła nie są już takie jak dawniej, na ich powierzchni pojawiły się naloty, których nie sposób usunąć, ale dzięki umiejętnej konserwacji i wymianie wszystkich profili ołowianych będą mogły przetrwać następne wieki. Jest to niezwykle czasochłonna praca, ale dla mnie to rodzaj dialogu z artystami, którzy tworzyli te dzieła, dialogu dającego możliwość odczytywania krok po kroku ich sposobu myślenia o projektowaniu i realizowaniu witraży. Podczas rozbierania każdej kwatery z ołowiu, wyciągania i oczyszczania pojedynczego, nawet najmniejszego szkiełka (fot. 13) można odczytać, jak wiele lat temu robiono witraże - jakich używano szkieł, jak je malowano patynami, emaliami i srebrem, jakiego ołowiu używano, jaka była technologia składania. Można znaleźć również szkła, które pękały w trakcie składania lub wypalania, co spowodowało dodanie kreski ołowiu niezamierzonej w projekcie. Czasami zaskakują szkła, które składały się z dwóch warstw położonych na sobie, a czasami dziwi ogromna różnorodność grubości tych sąsiadujących ze sobą. Dzięki wysokiemu sercu ołowiu, w którym były składane (czyli pionowej jego części), oraz kitowaniu te szkła mogły koło siebie zaistnieć. Na każdym pojedynczym szkle widać też ślady czasu. Lekkie zmatowienie powierzchni kontrastuje z błyskiem fragmentów, które przykryte ołowiem uchronione zostały od zmian. Można też odczytać to, że niektóre szkła były trzymane w piecu witrażowym 


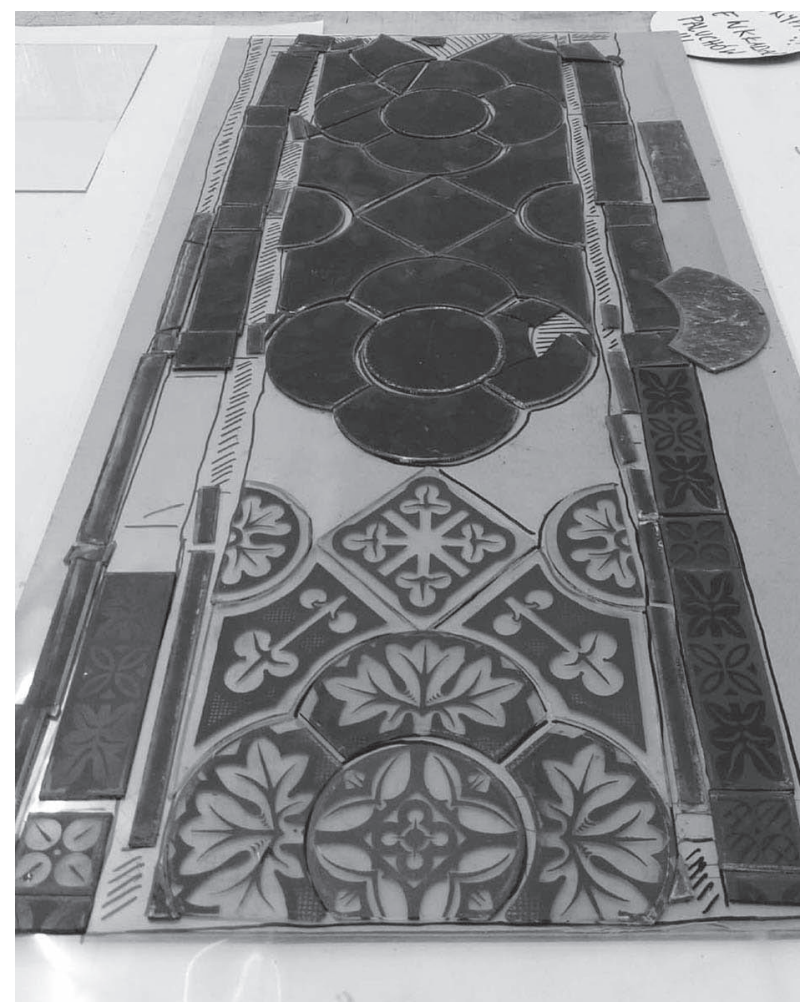

Fot. 13.

dłużej albo znajdowały się w tej jego części, gdzie panowała wyższa temperatura, a ich brzegi zostały lekko nadtopione. Kiedyś, gdy rozbierałam witraż, zaskoczyło mnie zachowanie szkieł, które kruszyły się w rękach jak herbatniki - każde szkło jest inne, inaczej reaguje na czas i warunki atmosferyczne. Niektóre mają ubytki malatury, które należy uzupełnić. Nigdy jednak nie wiemy, jak wiekowe szkło zachowa się, będąc ponownie pod wpływem wysokiej temperatury - i dlatego robi się próby. Czasami wytrzymuje je ono bez problemu, a czasami traci swoją przezroczystość i musi zostać zrekonstruowane.

Niektóre witraże, które w odpowiednim czasie nie zostały prawidłowo zakonserwowane, ulegają takiemu zniszczeniu, że wymagają zupełnej rekon- 
strukcji. Miałam okazję pracować przy rekonstrukcji witraża heraldycznego z XIX wieku (fot. 14-19). Na tyle późno oddano go do konserwacji, że można było zachować jedynie nieliczne jego szkła. Całość wymagała bardzo precyzyjnego skopiowania skomplikowanego rysunku herbu na podstawie tego, co się zachowało. Pomogła w tym symetryczność kompozycji labrów wokół herbu

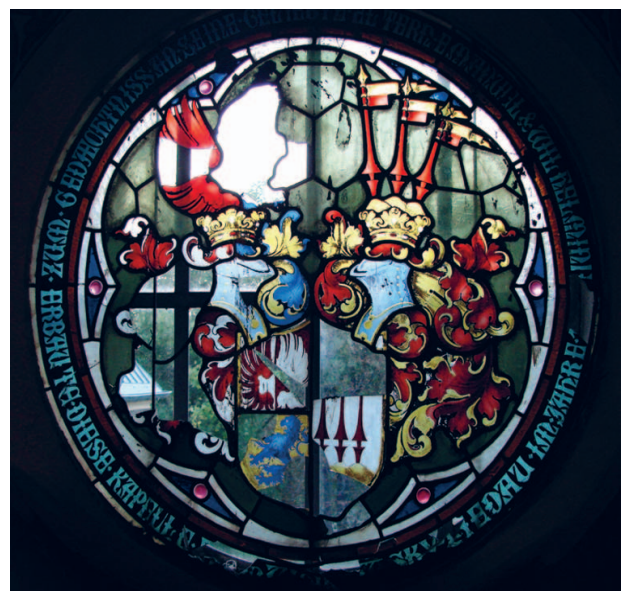

Fot. 14 .

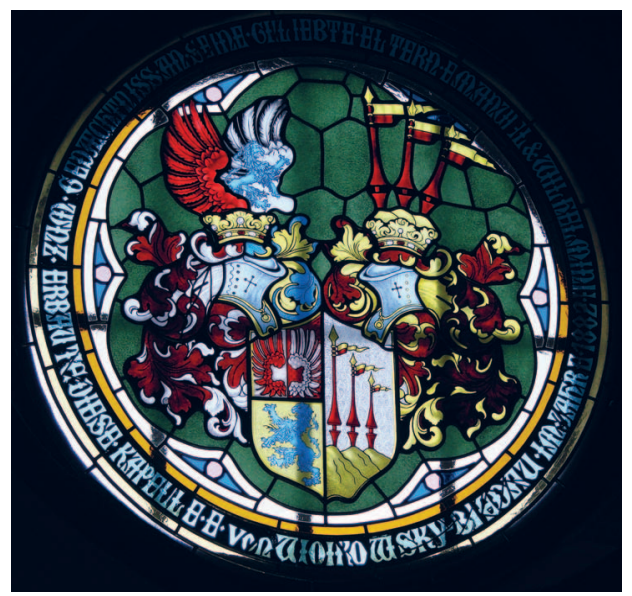

Fot. 15.

oraz odnalezienie oryginalnego wzoru w herbarzu. Wokół przedstawienia heraldycznego zamieszczono inskrypcję w języku niemieckim dotyczącą fundatora i roku powstania kaplicy, do której witraż ten przeznaczono. Niestety inskrypcja została w dużym stopniu zniszczona, dlatego znowu trzeba było odnieść się do przeszłości, poszukać materiałów i dokumentów. Dla mnie to rodzaj przeciwstawiania się czasowi i nierównej walki z nim, ale tak zrekonstruowany witraż powróci na swoje pierwotne miejsce i będzie opowiadał swoją historię. Cenne jest to, że dzięki umiejętnej konserwacji dawne witraże przetrwały do dzisiaj, ciągle zachwycają i są świadkami zmieniających się czasów. I może lepiej nie uświadamiać sobie tego, jak wiele dzieł sztuki witrażowej zostało bezpowrotnie utraconych, ponieważ nie potrafiły oprzeć się wichrom historii. 


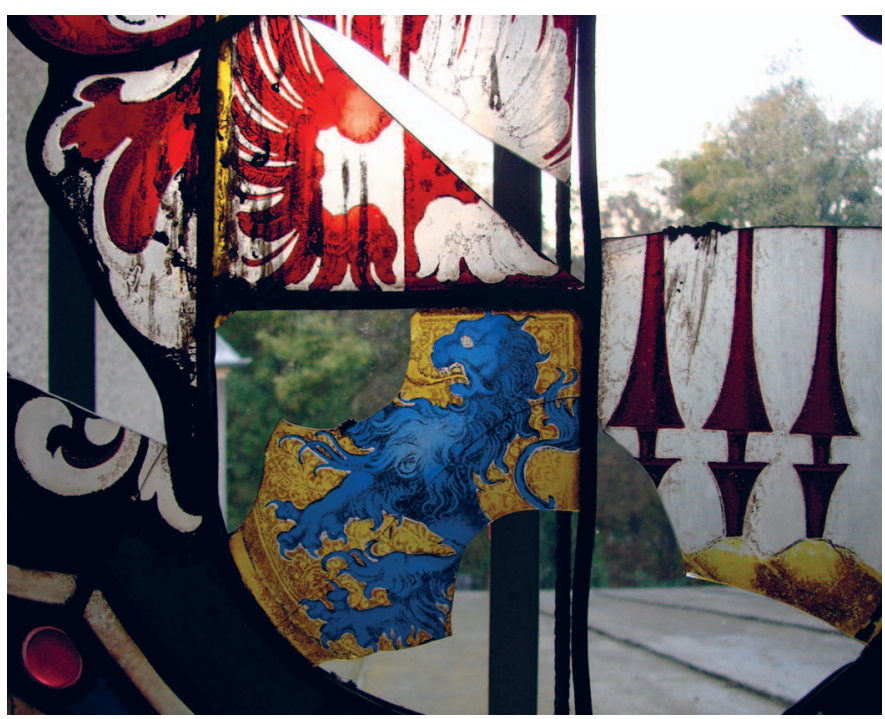

Fot. 16.

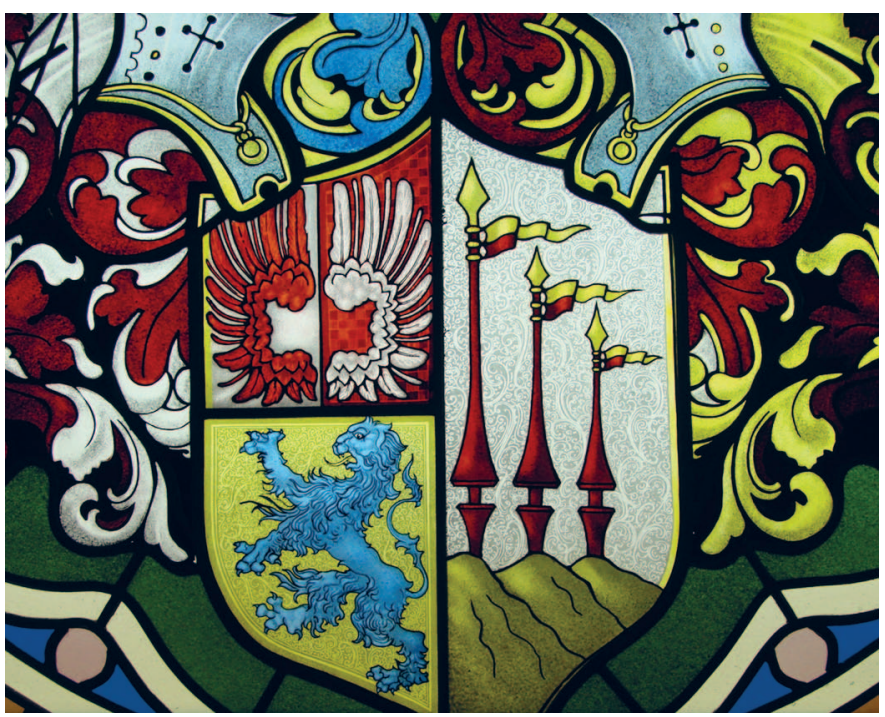

Fot. 17. 


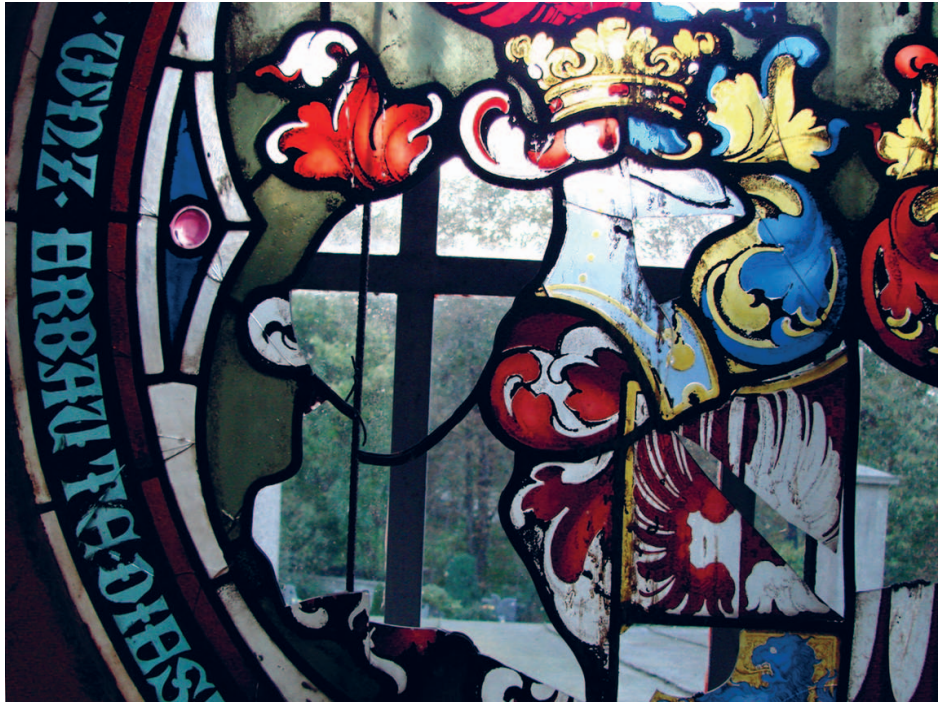

Fot. 18.

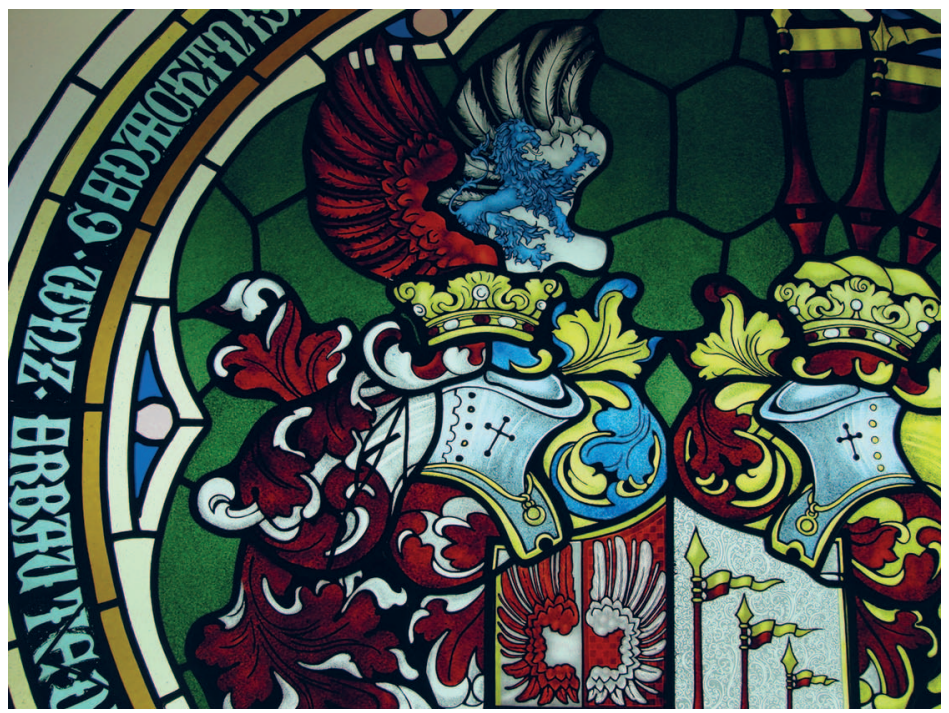

Fot. 19. 
[...] w imię Pana oraz poleceniu św. Pawła Apostoła: Raczej niech pracuje, czyniąc rękami swoimi coś dobrego, aby miat $z$ czego udzielić cierpiacemu niedostatek (Ef 4,28). Pragnąc to naśladować, zbliżyłem się do przedsionka świętej Mądrości i ujrzałem sanktuarium wypełnione na wszelki sposób przepyszną różnorodnością rozmaitych barw i ukazujące ich nadzwyczajną użyteczność oraz właściwości. Postąpiwszy ostrożnie dalej, napełniłem wystarczająco szkatułę mego serca tymi wszystkimi rzeczami, które dokładnie sumiennym badaniem zgłębiłem, i każdą, wzrokiem i rękoma wystarczająco udokumentowawszy, bez zawiści tobie powierzyłem. Ponieważ odpowiedniej znajomości tego rodzaju malarstwa nie da się natychmiast nabyć, starałem się najpierw wnikliwie różnymi sposobami poznać, $\mathrm{w}$ jaki sposób umiejętnością sztuki i rozmaitością barw przyozdobić dzieło, nie wyłączając światła dziennego i promieni słonecznych. Zastosowawszy się do tych wskazań, zrozumiałem naturę szkła i stwierdziłem, że tego rodzaju efekt można osiągnąć przez właściwe użycie szkła i wykorzystanie jego różnorodnych właściwości; tę sztukę, której nauczyłem się przez obserwację i przysłuchiwanie, starałem się rozwikłać na twój użytek ${ }^{4}$.

Dawno temu alchemicy poszukiwali kamienia filozoficznego, eliksiru nieśmiertelności i lekarstwa na wszelkie choroby, próbowali też zamienić ołów w złoto. Może właśnie ta sztuka udała się witrażystom, ponieważ dzięki temu srebrzystemu metalowi stworzyli unikatowe przeszklenia, które przetrwały do dziś. Niesamowite obrazy, które w ostateczności buduje przenikające przez kolorowe szkła światło, zmieniając je od świtu do zmierzchu, zarazem nadając wnętrzom niepowtarzalny klimat. Niewątpliwie o istocie witraży stanowi szkło, ale bez zastosowania ołowiu nie mogłyby one zaistnieć.

\section{Bibliografia}

Prezbiter T.: Diversarum Artium Schedula i inne średniowieczne zbiory przepisów o sztukach rozmaitych. Tyniec. Wydawnictwo Benedyktynów, Kraków 2009.

\footnotetext{
${ }^{4}$ Tamże, s. 31.
} 
Katarzyna Pyka - dr hab., prof. UŚ. W 2000 roku ukończyła studia z wyróżnieniem w Instytucie Sztuki Uniwersytetu Śląskiego w Katowicach, realizując dyplom z grafiki artystycznej oraz rysunku. W 2002 roku ukończyła również studia podyplomowe na Akademii Sztuk Pięknych we Wrocławiu, realizując pracę dyplomową z zakresu witrażu w pracowni prof. Ryszarda Więckowskiego. W tym samym roku rozpoczęła pracę w macierzystej uczelni, prowadząc pracownię rysunku. W 2007 roku zorganizowała w Instytucie Sztuki pracownię witrażu i szkła artystycznego. W 2006 roku zrealizowała doktorat w dziedzinie sztuk plastycznych, w dyscyplinie sztuki piękne. W 2007 roku uzyskała stypendium Ministra Kultury i Dziedzictwa Narodowego. Stopień doktora habilitowanego w dziedzinie sztuk plastycznych, w dyscyplinie sztuk projektowych, uzyskała na Akademii Sztuk Pięknych we Wrocławiu w 2013 roku. Zajmuje się grafiką, rysunkiem oraz szkłem. Swoje prace prezentowała na dwudziestu indywidualnych wystawach oraz na ponad stu wystawach zbiorowych w kraju i za granicą. 